\title{
SHARED VALUE AND ITS REGIONAL AND INDUSTRIAL REFLECTION IN CORPORATE PROJECTS
}

\section{Křečková Kroupová, Z.}

The article analyzes Shared Value (CSV) implemented projects by regions, social issues, and industries that are involved in pursuing the CSV concept. Project preferences by region show South America, Central America and Caribbean, Global scope and Africa as key targets of CSV projects, followed by North America and Asia. Europe, both Western and Eastern, is at the edge of interest with only several projects implemented. Project preferences by industry clearly show that companies capitalize on their strengths and professional focus. Analyzed Shared Value projects proved simultaneous value to a wide range of corporate stakeholders by creating new products or services, redefining productivity in the value chain or enabling local cluster development. Given the strategic nature of CSV projects, top management initiative is necessary. Numerous worldwide proven Shared Value business cases could serve as inspiration for Central European leaders in creation of their future strategies. Successful CSV projects implemented in the Czech Republic are mentioned.

Keywords: shared value; corporate social responsibility; stakeholders JEL classification: M14, L21, Q56

\section{Introduction}

Shared value is a corporate strategy discovering new business opportunities by solving pressing social problems, such as weaknesses in health and education systems, inequalities, lack of economic opportunities or threatened natural resources. The idea of shared value has been evolving for more than a decade. Already at the beginning of the millennium, Porter and Kramer (2002) explained that corporate philanthropy projects should be context-focused and bring also financial benefits for the company. Their description of the 'Convergence of Interests' graphically demonstrates the area of desired combined social and economic benefit (Porter and Kramer, 2002). However, they still label the effort as good 'corporate philanthropy'.

Another very early work, related to maximizing both social and business benefit from CSR programs, played with the label Corporate Social Opportunity (Grayson and Hodges, 2004). The authors defined the seven-step model guiding managers through desired changes to business strategies, and consequently corresponding changes to operational practices. Both early works stress that the 'corporate philanthropy' or Corporate Social Opportunity have to be part of corporate strategy.

In 2006, Porter and Kramer brought more refined approach providing practical guidance in assessing the social opportunities to be addresses. They introduced three types of social issues - Generic Social Issues, Value Chain Social Issues and Social Dimensions of Competitive Context reflecting CSR from Responsive CSR to Strategic CSR. The financial crisis, starting in 2008, caused shrinking of corporate philanthropy, charity and CSR budgets. So, the crisis situation even intensified the search for social 
projects that are not only costs, but also generating profit for a company. And Porter and Kramer introduced the idea of Shared Value as a solution. "Shared Value can be defined as policies and operating practices that enhance the competitiveness of a company while simultaneously advancing the economic and social conditions in the communities in which it operates" (Porter \& Kramer, 2011). Shared value should be driving innovation and productivity growth in the global economy in three ways (Porter \& Kramer, 2011):

- Reconceiving Products and Markets: Improving access to products and services fulfilling societal needs and consequently create new market and revenue for the company,

- Redefining Productivity in the Value Chain: Increasing company productivity by helping to solve social and environmental problems affecting quality and efficiency in the company operations,

- Enable Local Cluster Development: Improving the operating context influencing one's own business, such as the viability of supporting industries or access to qualified and skilled labor to enhance the business growth.

Shared Value was suddenly clearly positioned towards former CSR as the only way to bring simultaneously social and economic benefits. CSR is a more general concept when compared to CSV as there is no single definition of CSR. The two most often cited ones define CSR as "the continuing commitment by business to contribute to economic development while improving the quality of life of the workforce and their families as well as of the community and society at large" (WBCSD, p. 3) and the European Commission puts forward a new definition of CSR as "the responsibility of enterprises for their impacts on society" (EC, 2011, p. 6). CSR was mostly about taking resources from the business and investing them into ethical, social and environmental activities like philanthropy, volunteering, charities, etc. The CSR activities were often not directly connected with the core business of the company; hence the resources were often ill allocated. The recent financial crisis sharply reduced companies' willingness to spend on CSR activities that were perceived as costs. CSR was criticized as "window dressing" (Friedman, 1970), increasing costs, violation of profit maximization, lack of skills, lack of accountability and too much power in the hands of entrepreneurs (Robbins \& Coulter, 2012, p.126), being illusion, only a PR tool, ineffective in resource allocation (Karnani, 2010). So, the CSV concept offering a combination of profit generation and addressing social and environmental issues at the same time, catapulted itself into the strategic interest of managers. Table 1 summarizes the key differences between CSR and Corporate Shared Value (CSV). 
Table 1 | Differences between the concepts of Corporate Social Responsibility and Corporate Shared Value

\begin{tabular}{|l|l|}
\hline Corporate Social Responsibility (CSR) & Corporate Shared Value (CSV) \\
\hline Value: doing good & Value: economic and societal benefits to cost \\
\hline Citizenship, philanthropy, sustainability & Joint company and community value creation \\
\hline Discretionary or in response to external pressure & Integral to competing \\
\hline Separate from profit maximization & Integral to profit maximization \\
\hline $\begin{array}{l}\text { Agenda is determined by external reporting and } \\
\text { personal preferences }\end{array}$ & $\begin{array}{l}\text { Agenda is company specific and internally } \\
\text { generated }\end{array}$ \\
\hline $\begin{array}{l}\text { Impact limited by corporate footprint and CSR } \\
\text { budget }\end{array}$ & Realigns the entire company budget \\
\hline
\end{tabular}

Note: In both cases, compliance with laws and ethical standards and reducing harm from corporate activities are assumed.

Source: Porter and Kramer (2011)

The key social issues with connection to business potential were defined as: Energy Use, Water Use, Employee Health, Workforce Safety , Employee Skills, Supplier Access and Viability, Environmental Impact (Porter \& Kramer, 2011).

Ten Building Blocks of creating shared value, guiding from vision and strategy to implementation and monitoring, were presented by Bockstette and Stamp (2011, p. 9), stressing that "shared value starts with an explicit strategic decision by corporate leaders" (Bockstette \& Stamp, p. 10).

Companies from different industries pursued CSV projects in different regions of the world. The Shared Value Initiative (SVI) has been collecting its experiences in its Shared Value Case Examples database. SVI is a global community that, in close collaboration with Porter and Kramer, is connecting practitioners in search of the most effective ways to implement shared value.

The research questions are following:

1. Are any regions more attractive for CSV projects? What is the position of Central Europe?

2. Are industries really capitalizing on their strengths? Are they really focusing on the projects of their dominant expertise?

\section{Methods}

The status of CSV implemented projects was assessed based on the Shared Value Case Examples database of the Shared Value Initiative (SVI), the leading platform for practitioners of the CSV in July 31, 2015. The case examples of CSV project implemented by different corporations worldwide are presented in the voluntary database. The author of this article presumes corporations implementing CSV projects to also be active participants of SVI, hence presenting a successfully implemented project in the database. 
Descriptive statistics were used as a data analysis method. The SVI database covers 117 implemented CSV projects. Each project was identified by qualitative data, namely the social issue addressed, the region of the project implementation and the industry of the respective company. Many CSV projects tackle more than one social issue.

There are eleven areas of Social Issues defined by the list of SVI, where the CSV concept is implemented: Climate Change and Environment, Community Development, Disaster Preparedness, Response and Relief, Education, including Workforce Development, Financial Inclusion, Health and Nutrition, Human Rights, Poverty, Water, Women's Empowerment, Others. All presented projects were assessed by the social issue solved and the region of implementation. Another way of analysis was assessment by the social issue and the industry of the corporation implementing the project.

\section{Results}

Community Development (18\%, 30 projects), Education (17\%, 29 projects) and Health and Nutrition $(17 \%, 28$ projects), followed by Poverty (10\%, 17 projects) and Financial Inclusion $(10 \%, 16$ projects) are the most frequent social issues addressed by CSV projects.

Figure 1 | CSV projects by social issue

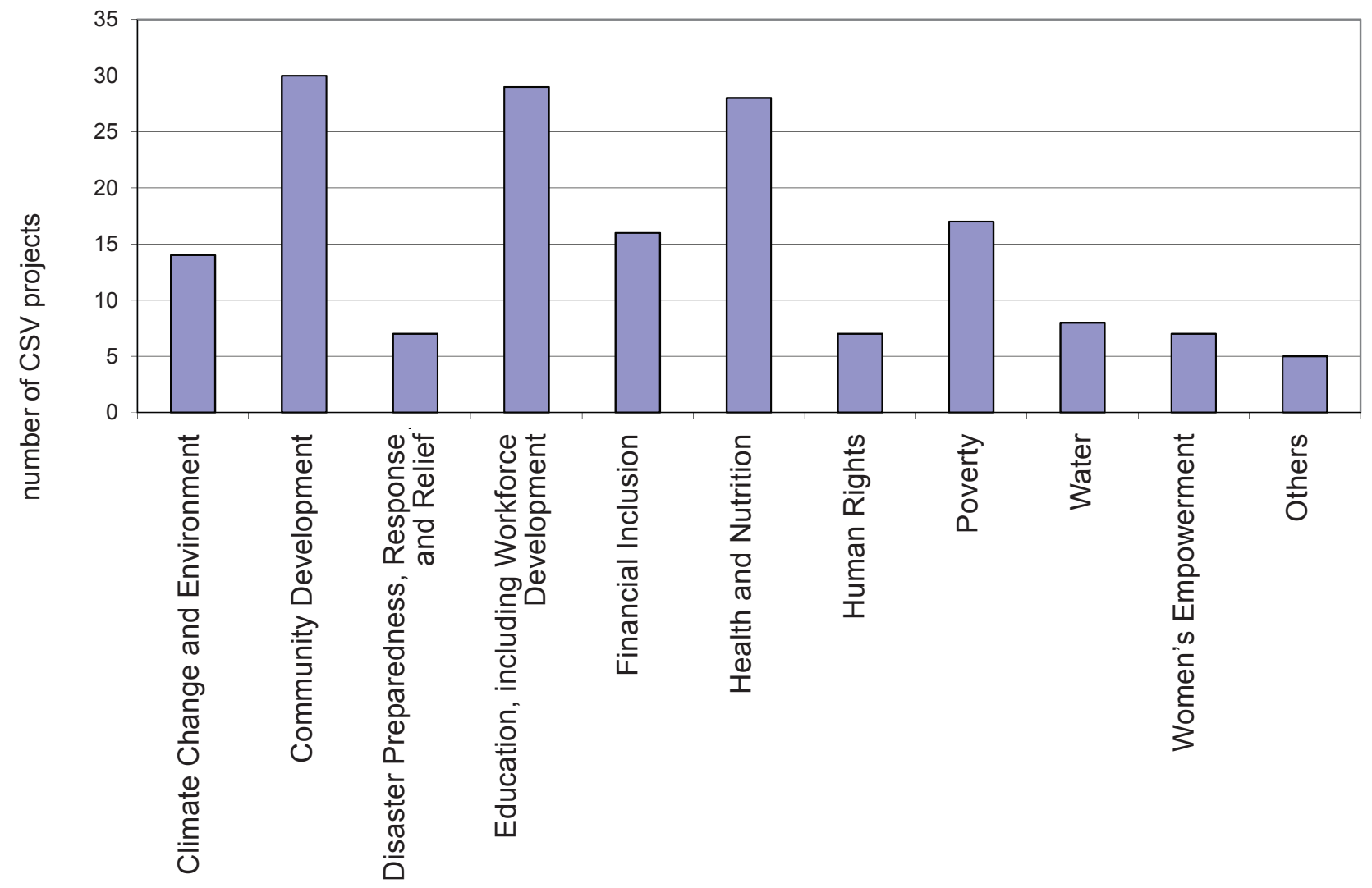

Source: author's analysis of SVI (2015) 


\section{CSV Projects Viewed by Regional Perspective}

The regional distribution of CSV projects is very irregular. Global span (22\%, 26 projects) and the region of South America, Central America and Caribbean (22\%, 26 projects) are of the highest occurrence of CSV projects. The following regions are Africa (18\%, 21 projects), North America (14\%, 16 projects) and Asia (14\%, 16 projects). Low presence is shown in Australia, New Zealand and South Pacific (6\%, 7 projects) and in Western Europe (3\%, 4 projects). The region Eastern Europe, Russia and Central Asia indicates only one realized project. There are no projects indicated in the region Middle East and North Africa.

\section{Figure 2 | CSV projects by regions}

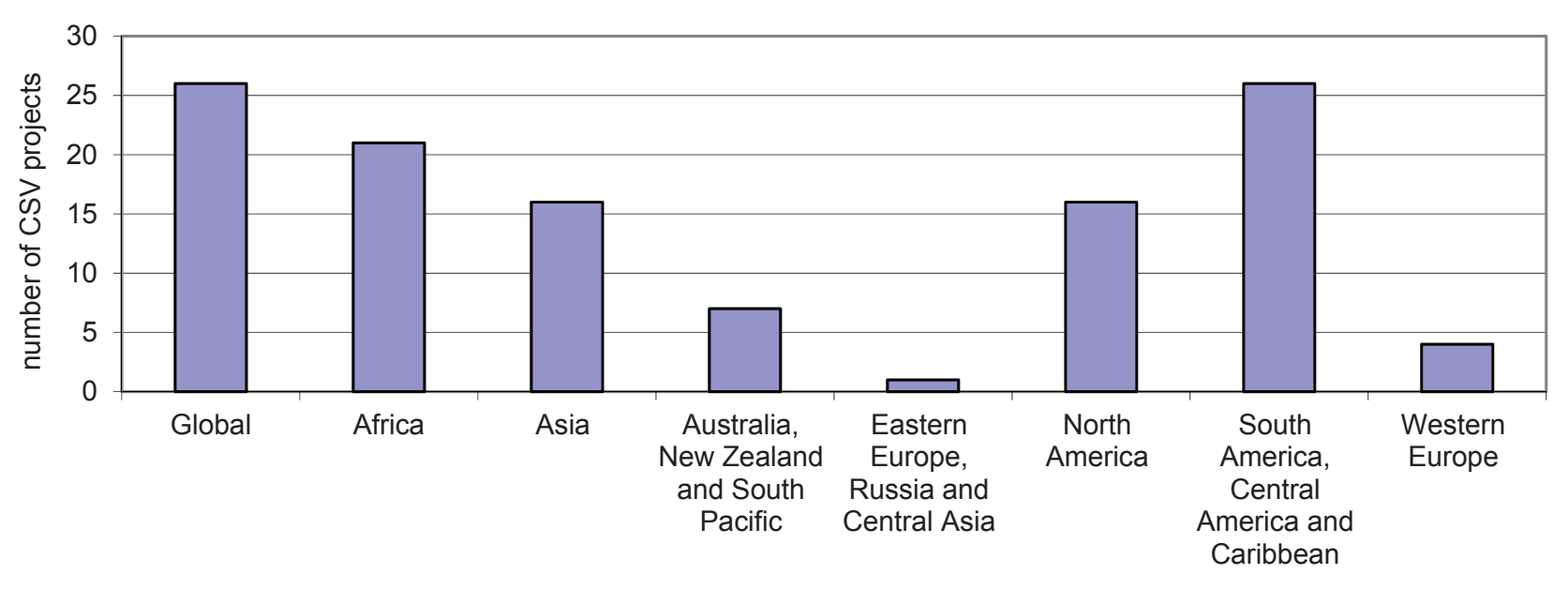

Source: author's analysis of SVI (2015)

When combining two criteria, region and social issue solved, Global scope projects focused mostly on Health and Nutrition (21\%, 9 projects) and Education (19\%, 8 projects), then on Poverty, Human Rights, and Financial Inclusion (9\%, 4 projects each). Projects in the region South America, Central America and Caribbean addressed the whole spectrum of social issued defined, with the most numerous projects in Education $(27 \%, 10$ projects) and Community Development (25\%, 9 projects), followed by Financial Inclusion $(11 \%, 4$ projects), Health and Nutrition and Climate Change and Environment (8\%, 3 projects both). Projects in Africa chose mostly issues in Health and Nutrition (27\%, 8 projects), Community Development (20\%, 6 projects), Poverty (17\%, 5 projects), and Education (13\%, 4 projects).

CSV projects in Asia focused mostly on Community Development (27\%, 6 projects), followed by Poverty and Health and Nutrition (17\%, 4 projects both), and Water (13\%, 3 projects). Projects in North America covered the whole spectrum of social issues. Most projects solved Community Development and Poverty (16\%, 5 projects both), then Financial Inclusion and Health and Nutrition (13\%, 4 projects both). Projects in Australia, New Zealand and the South Pacific addressed mainly Climate Change and Environment, Community Development and Health and Nutrition (25\%, 2 projects each). Projects in Western Europe dealt mainly with Climate Change and Environment (40\%, 2 projects), then with Financial Inclusion, Health and Nutrition and Others (20\%, 1 project each). The 
region Eastern Europe, Russia and Central Asia presented only one Shared Value project in Turkey focusing on Education.

Figure 3 | CSV projects by region and social issue

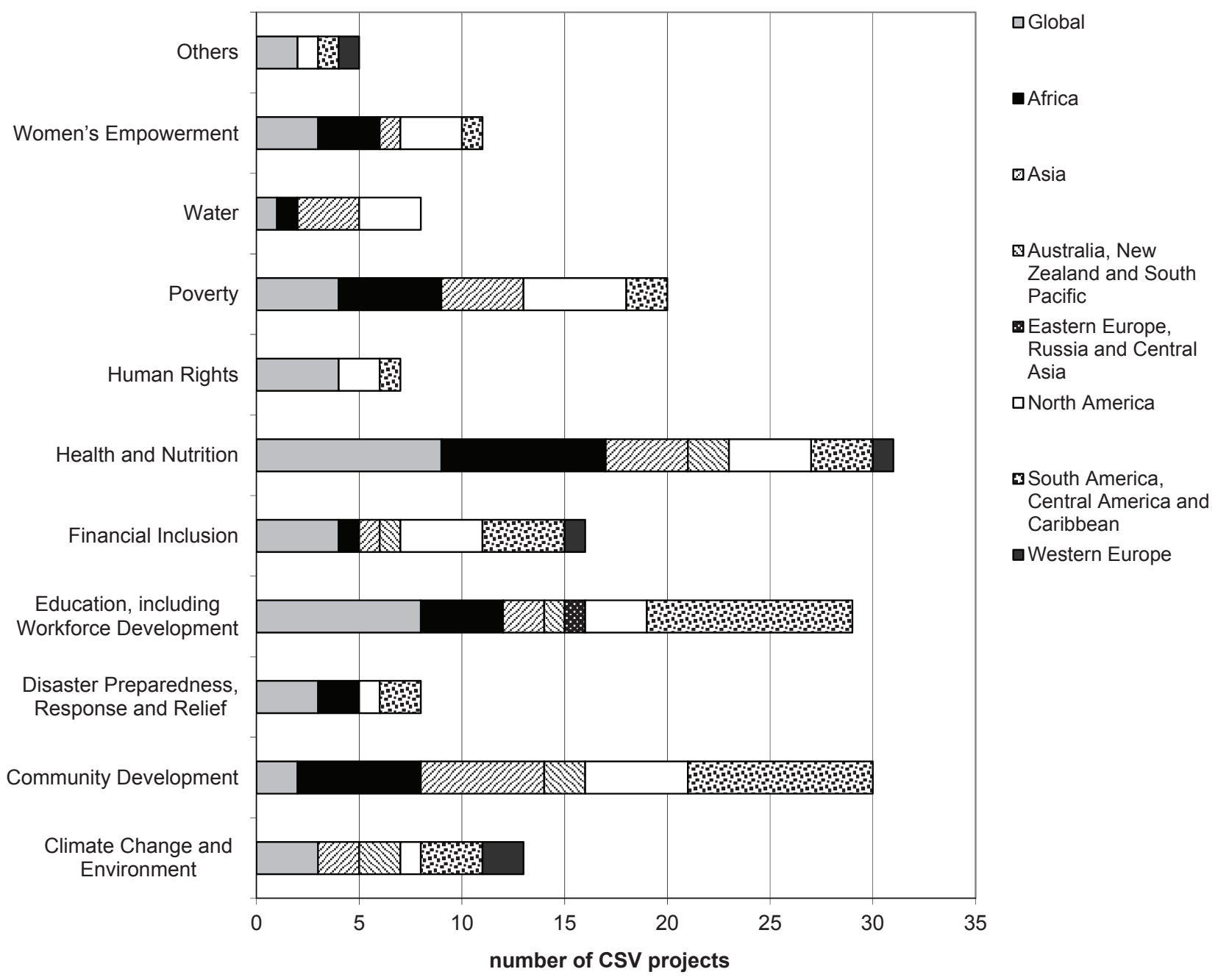

Note: Some projects solve more than one social issue.

Source: author's analysis of SVI (2015)

\section{Shared Value Projects in the Czech Republic}

Surprisingly, the database does not cover several CSV projects that were designed and implemented in the Czech Republic. Companies focused on solving social issues Climate Change and Environment, Community Development, Education, including Workforce Development, Financial Inclusion, Health and Nutrition, Water.

T-Mobile and Nestlé focused on social issue Climate Change and Environment. T-Mobile implemented several projects: reduction of $\mathrm{CO}_{2}$ emissions by enabling remote access to office; offering tailor-made client solutions enabling replacing travelling, printing, etc. by introducing ICT solutions; introduction of a WebDispatch system allowing optimization of a company car fleet; Smart Metering allowing monitoring and optimization of usage of water, energy and gas (Bockstette \& Stamp, 2012, p. 30-31). Nestlé focused on 
material reduction by packaging optimization (Bockstette \& Stamp, 2012, p. 36-37).

IKEA HANIM and Nestlé chose the social issue Community Development. Both companies focused on their intensive cooperation with local suppliers and helping them increase quality standards which evolved in long-term cooperation in regions with moderate level of unemployment (Bockstette \& Stamp, 2012, p. 34-37).

Česká spořitelna, Bayer and Cisco focused on the social issue of Education, including Workforce Development. Česká spořitelna initiated the project Social Enterprise Finance helping a new segment of potential customers get access to all banking services, especially by individual consultations and coaching (Bockstette \& Stamp, 2012, p. 26-27); the bank also pursues increasing financial literacy among both school children and senior citizens (Česká spořitelna, 2013). Both of the projects also solve the social issue Financial Inclusion. Bayer launched the project Science Has a Future (Věda má budoucnost) where the company closely cooperates with schools at elementary and high-school levels by bringing chemistry nearer to students (Bockstette \& Stamp, 2012, p. 32-33). The Cisco Networking Academy education program was launched to increase qualification of individuals interested in ICT. Cisco also participated in the curriculum reform of the educational system by co-defining standards for the educational program in the ICT area in the Czech Republic (Bockstette \& Stamp, 2012, p. 24-25).

The social issue Health and Nutrition was targeted by Nestlé. The company was a pioneer of voluntary nutrition labeling in the Czech Republic to fight obesity by increased product information for consumers; Nestlé also provided free MNA testing for early identification of seniors' malnutrition inhibiting their therapies. The company also offers, if needed, a portfolio of clinical nutrition products (Bockstette \& Stamp, 2012, p. 36-37).

The social issue Water was solved by T-Mobile with its project Smart Metering allowing monitoring and optimization of usage of water, energy and gas (Bockstette \& Stamp, 2012, p. 30-31).

\section{CSV Projects Viewed by Industrial Perspective}

When combining two criteria, industry and social issue solved, the highest occurrence of CSV projects are in Energy and Extractives and Nonprofits and NGOs, followed by Education, Financial Services, Healthcare, Pharmaceuticals and Biotechnology and Others.

Projects in Energy and Extractives dealt mainly with Community Development (28\%, 9 projects), Education, incl. Workforce Development (21\%, 7 projects), Climate Change and Environment (12\%, 4 projects), then Water and Health and Nutrition (9\%, 3 projects each); a few projects focused on Poverty, Human Rights, and Financial Inclusion $(6 \%, 1$ project each area).

Projects in Non-profit and NGOs dealt mainly with Poverty (17\%, 5 projects) and Women's Empowerment (14\%, 4 projects), then Community Development, Disaster Preparedness and Education (11\%, 3 projects each).

Projects in the Education industry focused mostly on social issue of Education, incl. Workforce Development (48\%, 9 projects), Poverty (16\%, 3 projects) and Financial Inclusion (11\%, 2 projects), then less on Disaster Preparedness, Community Development, Women's Empowerment, Human Rights and Health and Nutrition (5\%, 1 project each). 


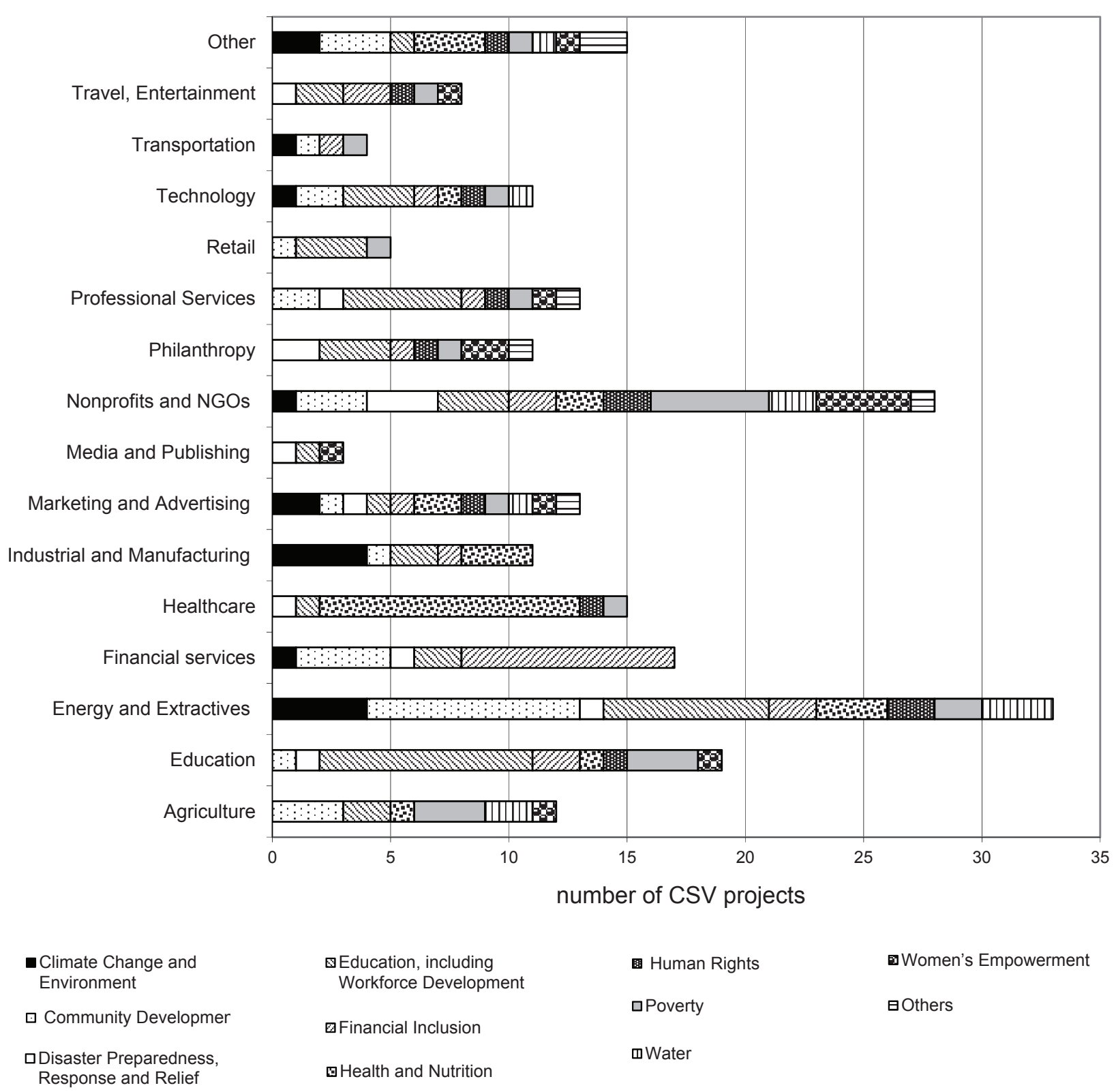

Note: Many projects solve more than one social issue.

Note II.: industries' names were shortened in the following way: Travel, Enter-tainment = Travel, Entertainment, Sport and Hospitality; Transportation, incl. logistics and distribution; Technology, incl. communication; Retail, incl. restaurants and food service; Professional Services, incl. consulting, legal, tax, and real estate; Healthcare $=$ Healthcare, Pharmaceutical and Biotechnology; Financial services, incl. including banking and insurance.

Source: author's analysis of SVI (2015)

Projects in Financial services focused primarily on Financial Inclusion (52\%, 9 projects), followed by Community Development (24\%, 4 projects) and Education (12\%, 2 projects).

Projects in Healthcare, Pharmaceutical and Biotechnology addressed dominantly the social issue of Health and Nutrition (72\%, 11 projects), then Disaster Preparedness, Education, Human Rights and Poverty (7\%, 1 project each). 
Projects in Professional services, incl. consulting, legal, tax, and real estate focused mostly on social issue Education (37\%, 5 projects) and Community Development (15\%, 2 projects).

The outcomes of the industrial and social issue analysis show that companies focused on their strengths and expertise when choosing social issues to be solved by CSV projects. The companies from industries Education and Professional services solved the social issue Education in $48 \%$ and in 37\%, Non-profit and NGOs' major focus was on Poverty and Women's Empowerment, Financial Services in 53\% focused on Financial Inclusion and Healthcare, Pharmaceutical and Biotechnology in $72 \%$ solved Health and Nutrition social issues.

\section{Conclusion, Managerial Implications and Future Research}

The Shared Value idea has developed for more than a decade. It slowly crystallized into a clear corporate strategy, focusing both on social and economic issues, strong enough to meet the expectations of a wide group of company stakeholders. The initial list of social issues suggested by Porter and Kramer, was more refined to reflect the implemented projects by Shared Value Initiative. Nearly 120 successful projects have been documented so far.

Project preferences by region show South America, Central America and Caribbean, Global scope, and Africa as key targets of CSV projects, followed by North America and Asia. The regions Western and Eastern Europe, Russia and Central Asia are of very little interest. The region Middle East and North Africa demonstrates no attractiveness for CSV projects.

Regarding managerial implications, project preferences by industry clearly show that companies are capitalizing on their strengths by designing and implementing projects where their core expertise is used. The key CSV drivers are either reconceiving products or markets, redefining productivity in the value chain or enabling local cluster development. Analyzed projects prove that a company can help solve social/environmental issues and generate profit simultaneously. The viability of these projects also presents the idea of Shared Value as a good corporate strategy. This is a great improvement and good news for shareholders, compared to earlier fragmented philanthropy and CSR projects, often unrelated to business activities of companies.

The analysis shows polarizing regions, where some display enormous attractiveness for CSV projects, while others seem to be untouched. Even though there might be several uncharted projects, there is space for future research. Identifying key enablers attracting CSV projects into the region could help both regions and companies.

\section{References}

Bockstette, V., \& Stamp, M. (2011). Creating Shared Value: A How-to Guide for the New Corporate (R)evolution. Retrieved June 20, from http://www.fsg.org

Bockstette, V., \& Stamp, M. (2012). Vytvárení sdílené hodnoty: Průvodce novou firemní (r)evolucí. Prague: FSG.

Česká spořitelna (2013). Česká spořitelna a Terra-klub společně vydali Školní atlas Dnešní finanční svět akreditovaný ministerstvem školství [Press release]. Retrieved July 30, 2015 from http://www.csas.cz/banka/content/inet/internet/cs/news_ie_1809.xml 
EC (2011). A renewed EU strategy 2011-14 for Corporate Social Responsibility. European Commission. Retrieved August 18, 2015 from http://eur-lex.europa.eu/legal-content/EN/ TXT/?uri=CELEX:52011DC0681

Grayson, D., \& Hodges, A. (2004). Corporate Social Opportunity!: 7 Steps to Make Corporate Social Responsibility Work for Your Business. Greenleaf Publishing, 2004

Friedman, M. (1970). The Social Responsibility of Business Is to Increase Its Profits. The New York Times. Retrieved May 21, 2015 from http://query.nytimes.com/mem/archive-free/ pdf?res=9E05E0DA153CE531A15750C1A96F9C946190D6CF.

Karnani, A. (2010). The case against corporate social responsibility. Wall Street Journal, 23, 1-5.

Porter, M. E., \& Kramer, M. R. (2002). The Competitive Advantage of Corporate Philanthropy. Harvard Business Review, December 2002.

Porter, M. E., \& Kramer, M. R. (2006). Strategy \& Society The Link Between Competitive Advantage and Corporate Social Responsibility. Harvard Business Review, December 2006.

Porter, M. E., \& Kramer, M. R. (2011). Creating Shared Value. How to reinvent capitalism - and unleash a wave of innovation and growth. Harvard Business Review, 89(1/2), 62-77.

Robbins, S. P., \& Coulter, M. (2012) Management. 11th ed. New Jersey: Prentice Hall.

SVI (2015). Shared Value Case Examples database (Shared Value Initiative) [Data file]. Retrieved July 30, 2015 from http://sharedvalue.org/example-listing?keys=\&field_industries_ tid=All\&field_geography_tid=All\&field_resource_social_issue_tid=1776.

WBCSD (n.d.) Corporate Social Responsibility. World Business Council for Sustainable Development [Report]. Retrieved August 18, 2015 from http://www.wbcsd.org/pages/ edocument/edocumentdetails.aspx?id=82\&nosearchcontextkey=true.

\section{Author}

\section{Ing. Zuzana Křečková Kroupová, M.A., Ph.D.}

Assistant Professor

Department of Retailing and Commercial Communications

Faculty of International Relations

University of Economics, Prague

W. Churchill Sq. 4, 13067 Prague, Czech Republic

zuzana.kreckova@vse.cz 